\title{
DINAMIKA HUKUM DAN HAK ASASI MANUSIA DI NEGARA-NEGARA MUSLIM
}

\author{
Muhammad Hafiz \\ Program Manager UN-OIC Advocacy Human Rights Working Group (HRWG), Jakarta \\ e-mail: hafizmuhammad85@gmail.com
}

\begin{abstract}
Muslim countries often stuck in a dilemmatic situation between be exclusively with retaining the Islamic principles of human rights through Islamic law or follow the principles of human rights which is regulated internationally through Universal Declaration of Human Rights (UDHR). The existence of Independent Permanent Commission of Human Rights (IPHRC) as one of the core institutions of organization of the Islamic Cooperation (OIC) intended to be a mediator for the occurrence of constructive dialogue between human rights discourse on one side with Islamic law on the other side. This is the way to reduce dichotomous view that impact on gaps and conflict. The equivalent dialogue continuously between two entities, Islamic law and human rights must always be attempts to open opportunities in more widely shared understanding and in turn will facilitate the achievement of progress and the protection of human rights in Muslim countries. This dialogue also important to remove the negative stigma against Islamic law that is often accused of violating human rights. and also to open space of interpretation to Islamic law that relevance with contemporary life.
\end{abstract}

Negara Muslim seringkali terjebak pada situasi yang dilematis antara bersikap eksklusif dengan mempertahankan prinsip-prinsip Hak Asasi Manusia (HAM) yang digariskan oleh Islam melalui hukum Islam, atau mengikuti prinsip-prinsip HAM yang diatur secara internasional melalui Universal Declaration of Human Rights (UDHR). Keberadaan Independent Permanent Commission of Human Rights (IPHRC), sebagai salah satu lembaga inti Organisasi Kerjasama Islam (OKI) dimaksudkan untuk menjadi mediator bagi terjadinya dialog konstruktif antara diskursus HAM di satu sisi dengan hukum Islam di sisi lain sehingga mampu mereduksi pandangan dikotomis yang berdampak pada kesenjangan dan konflik. Dialog setara yang terus-menerus antara dua entitas, hukum Islam dan HAM harus selalu diupayakan untuk membuka peluang yang lebih luas pada pemahaman bersama dan pada gilirannya akan memudahkan tercapainya kemajuan dan perlindungan HAM di negara-negara Muslim. Di sisi lain, dialog ini menjadi sarana penting bagi pembangunan diskursus HAM dan menghilangkan stigma negatif terhadap hukum Islam yang seringkali dituduh melanggar HAM, serta sebaliknya membuka ruang interpretasi dan kajian hukum Islam yang secara terus-menerus mengarah pada relevansi hukum Islam dalam kehidupan kontemporer.

Keywords: $\quad$ HAM, hukum Islam, IPHRC, OKI

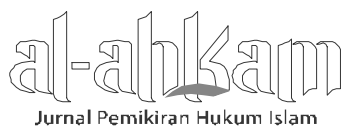

Volume 23, Nomor 2, Oktober 2013 


\section{Pendahuluan}

Perdebatan antara Islam dan hak asasi manusia (HAM) setidaknya melibatkan dua pendapat arus utama, yaitu pandangan antagonis dan akomodatif (negosiatif). Pandangan antagonis merupakan pandangan yang berkaitan erat dengan politik HAM itu sendiri pada masa-masa pasca perang dingin. Dengan segala kritik yang disampaikan kepadanya, ${ }^{1}$ tesis yang diajukan oleh Samuel P. Huntington nampaknya relevan untuk menggambarkan corak antagonis ini, karena Islam dan Barat dipandang saling mencurigai satu sama lain. ${ }^{2}$ Dalam hal ini, HAM seringkali dianggap sebagai salah satu alat kolonialisasi dan upaya Barat untuk menghancurkan peradaban Timur, secara khusus peradaban umat Islam. Prasangka ini mendorong hubungan antara dua peradaban ini tidak harmonis, dalam beberapa hal juga cenderung menafikan aspek positif di antara keduanya. Wacana HAM merupakan korban dari konflik peradaban ini, sehingga dalam perkembangannya wacana HAM cukup sulit diterima oleh negara-negara Timur dan umat Islam secara umum.

Pendapat kedua merupakan perspektif yang lebih bersifat akomodatif atau negosiatif, dengan mengedepankan negosiasi antara (syariat) Islam dan konteks kekinian, termasuk wacana HAM. ${ }^{3}$ Pandangan ini berkeyakinan, hanya dengan mengkompromikan dua pandangan yang seringkali diasumsikan bertentangan inilah justru yang dapat memajukan dan melindungi HAM di negara-negara Muslim, yang pada akhirnya mengarah kepada suatu kesatuan pandangan tentang pentingnya HAM itu sendiri, tanpa melupakan tradisi hukum Islam yang telah lama tumbuh dan berkembang. Dengan dua sumber nilai dan moral tersebut pula kemudian HAM mendapatkan momentumnya untuk semakin ditegakkan dan didesakkan pada tataran praktik di setiap negara karena didukung oleh dua pondasi moral dan peradaban penting di dunia. ${ }^{4}$

\footnotetext{
1Di antara kritik yang muncul adalah disampaikan oleh Ronald Inglehart dan Pippa Norris. Lihat lebih lanjut dalam tulisan keduanya, "The True Clash of Civilization" dalam Foreign Policy, No. 135, Maret-April., 2003, h. 62-70.

2Lihat: Samuel P. Huntington, The Clash of Civilization and the Remaking of World Order (New York: Simon and Schuster, 1996); Lihat pula, Samuel P. Huntington, "The Clash of Civilization?" dalam Foreign Affairs, Vol. 72, No. 3, Summer, 1993, h. 22.

3Pandangan ini setidaknya yang digunakan oleh Mashood A. Baderin dalam bukunya Hukum Internasional HAM dan Hukum Islam, (terj.) (Jakarta: Komnas HAM RI, 2007).

${ }^{4}$ Salah satu tokoh utama yang mengetengahkan perspektif ini adalah Abdullah Ahmed al-Na'im dalam buku Islam and Secular State. Untuk pertama kalinya buku ini diterbitkan dalam bahasa Indonesia oleh Mizan, sebelum buku tersebut diterbitkan dalam bahasa Inggris. Pandangan ini kemudian dilanjutkan dan dikembangkan oleh beberapa intelektual lain, seperti Mashood Baderin dalam bukunya
} 
Berpedoman pada pandangan yang kritis-konstruktif, artikel ini mencoba untuk meninjau perkembangan HAM di negara-negara Muslim dan mengunakan perspektif yang kedua, yaitu lebih mengarah pada menegosiasikan dua sumber standar nilai HAM tersebut untuk kemudian memberikan kontribusi dalam pembangunan dan perlindungan HAM yang lebih konkret.

\section{Politik Hak Asasi Manusia di Negara-negara Muslim}

Sebagaimana di atas, dalam buku The Clash of Civilization, Samuel P. Huntington meramalkan suatu perabadan dunia yang terpecah menjadi dua, setelah runtuhnya rezim komunis di negara-negara Timur. Runtuhnya komunisme tersebut, seiring dengan kuatnya nasionalisme dan melepaskan diri dari penjahahan, memunculkan suatu babak baru tentang tatanan dunia, yaitu Barat dan Timur, atau lebih spesifik adalah Islam. ${ }^{5}$ Pada fase ini, ditambah lagi dengan peristiwa dramatis Revolusi Iran yang mengukuhkan kembali Islam sebagai ideologi politik. Hubungan Islam dan Barat mulai sensitif terhadap pertentangan-pertentangan, baik ideologis atau politis. Kecurigaan kedua peradaban ini sama-sama memunculkan stereotipe, yang berujung pada hubungan yang tidak harmonis antara Islam dan Barat (Eropa). ${ }^{6}$

Asumsi Huntington di atas dapat dilacak konteks historisnya dari suatu sejarah kolonialisasi Barat yang merangsek hampir ke sebagian besar wilayah Muslim. Kolonialisasi yang menimpa masyarakat Muslim tersebut, distimulasi oleh kemajuan spektakuler yang telah diraih oleh masyarakat Barat, justru menimbulkan perasaan "ingin bangkit" di kalangan umat Islam. Umat Islam yang awalnya memiliki kejayaan tak tertandingi — pada beberapa abad yang silam— justru saat ini mundur dan tertinggal dengan kemajuan zaman. Masa jumud (kevakuman) selama hampir tujuh abad lebih menjadikan fase kejayaan peradaban Eropa ini sentilan pahit bagi umat Islam, dan membangunkan mereka dari tidur panjang. ${ }^{7}$

Hukum Internasional HAM dan Hukum Islam. Untuk melihat profil Abdullah al-Na'im, lihat http:// aw.emory.edu/faculty-and-scholarship/faculty-scholarship/an-naim-scholarship.html

5Lihat: Samuel P. Huntington, The Clash of Civilization ....

${ }^{6}$ Menurut beberapa analisa, adanya stretotipe atau kecurigaan di antara kedua peradaban ini sebetulnya berangkat dari kesalahan persepsi tentang Islam, yang di antaranya disebabkan oleh beberapa hal, yaitu anggapan bahwa Islam seringkali selalu menggunakan kekerasan, anti-Barat, dan selalu bereaksi secara sosial dan politik. Faktor ini diteliti oleh Marshall M. Bouton. Lihat: Parni Hadi, "Media and the Politic of Image Making", dalam Chaider S. Bamualim, dkk., Islam and The West (Jakarta: Konrad Adenauer Stiftung \& Center for Languages and Cultures, 2003), h. 55.

7Perlu dicatat, bahwa peradaban Iran yang merupakan basis Syi'ah agak berbeda dengan Sunni. Pada abad ke-17 M, dalam kondisi kejumudan dan kevakuman, masyarakat Muslim Syi'ah tengah 
Pada fase inilah, semangat umat Islam memuncak dan keinginan untuk menghidupkan kembali ajaran Islam mulai menjadi tujuan perjuangan. Salah satu adagium yang sangat mencuat saat itu adalah bahwa "Kemunduran umat Islam pada masa modern adalah karena mereka meninggalkan al-Qur'an sebagai rujukan utama umat Islam". Dorongan untuk kembali kepada sumber otoritatif inilah yang menguatkan pembaruan (tajdīd) di kalangan ulama Islam dan menandai sebuah masa baru pembukaan kembali pintu ijtihad, karena taqlïd (mengikuti secara kaku apa yang telah diwariskan oleh ulama terdahulu) dan penutupan pintu ijtihad merupakan titik pangkal kritik atas kemunduran umat Islam. ${ }^{8}$

Dengan spirit pembaruan dan stimulus yang datang dari peradaban Eropa (Barat) tersebut, setidaknya penyikapan umat Islam terbelah menjadi tiga tipe pendekatan yang berbeda-beda, meskipun identik, yaitu: apologetik, identifikatif, dan affirmatif.9 Melalui pendekatan apologetik, sebagian pemikir Muslim mengemukakan kelebihan-kelebihan Islam, yang termasuk di dalamnya adalah jihad, poligami, kedudukan perempuan, perbudakan dan lain-lain. Pendekatan ini cenderung idealistik dan normatif, serta mengabaikan realitas sosial, selain juga mencerminkan sikap reaksioner. Pendekatan identifikatif diambil untuk mengidentifikasi masalah-masalah yang dihadapi guna merumuskan respon dan sekaligus identitas Islam di masa modern. Terakhir, pendekatan afirmatif dilakukan untuk menegaskan kembali kepercayaan kepada Islam dan sekaligus menguatkan kembali eksistensi masyarakat Muslim itu sendiri.

mencari identitas kemajuan zaman. Saat itu, telah pula muncul Bāqir as-Ṣadr, yang menghidupkan tradisi pemikiran filsafat Islam. Menurut catatan Azyumardi Azra pula, masa stagnasi umat Islam pasca keruntuhan Dinasti 'Abbāsiyyah, telah muncul pada fase berikutnya tiga dinasti besar yang sempat menguasai sebagian besar wilayah dunia, yaitu Dinasti Utsmani di hampir seluruh Timur Tengah, Eropa Timur dan Asia Tengah, Dinasti Safawi di Pesia dan Dinasti Mughol, sempat menimbulkan kekuatan politik adidaya, namun tidak mampu memunculkan kekuatan di bidang lain, seperti teknologi dan ilmu pengetahuan. Lihat: Azyumardi Azra, Pergolakan Politik Islam: Dari Fundamentalisme, Modernisme, Hingga Pos-modernisme (Jakarta: Paramadina, 1996), h. iii; Lihat pula tentang kemunduran ilmu pengetahuan dinasti-dinasti ini dalam buku Philip K. Hitti, The History of Arabs, (terj.) (Jakarta: Serambi, 2008), h. 846-848.

${ }^{8}$ Salah satu dari sekian banyak intelektual Muslim yang mendorong terbukanya pintu ijtihad adalah Muhammad Abduh, yang cukup gigih memperjuangkan agama Islam dalam konteks masyarakat modern. Untuk Muhammad Abduh dan beberapa intelektual yang lain di Timur Tengah pada abad ke-17 sampai ke-20, lihat Albert Hourani, Arabic Thought in the Liberal Age: 1798 - 1939 (London: Cambridge University Press, 1983).

${ }^{9}$ Azyumardi Azra, Pergolakan Politik Islam, h. iv.

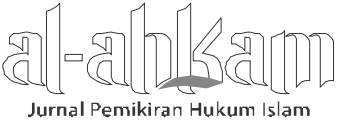


Pendekatan-pendekatan yang digunakan oleh intelektual Muslim untuk menjawab perkembangan zaman ini membedakan "out-put" sikap yang harus diambil dalam menjawab permasalahan-permasalahan sosial yang terjadi di sekitar masyarakat Muslim, terutama yang telah terdikotomi dengan sistem nation-state. Ketiga perspektif ini menjadi penentu pandangan seorang intelektual terkait isuisu demokrasi, hak asasi manusia, kewarganegaraan, serta hak-hak perempuan, yang juga merupakan titik sentral perdebatan dan polemik. Ditambah lagi, beberapa isu yang telah disebutkan di atas menjadi tuntutan moral dan standard nilai masyarakat modern yang telah mengglobal. Akhirnya, umat Islam dihadapkan pada beberapa pilihan yang harus ditentukan — diantaranya adalah ketiga pendekatan di atas - untuk tetap meyakini ke-memadai-an (sufficiency) Islam sebagai agama yang universal dan rahmatan lil alamin. ${ }^{10}$ Dengan perkataan lain, mengenai hubungan hak asasi manusia dan sistem nation-state, jika umat Islam hendak menerapkan syari'ah historis (menggunakan istilah al-Na'im), maka mereka tak akan dapat menggunakan hak-haknya untuk menentukan diri sendiri, tanpa mengorbankan hak-hak orang lain. ${ }^{11}$

Beragamnya sikap yang diperankan oleh para intelektual Muslim pada fase ini mencerminkan dua kecenderungan besar, terutama dalam penggunaan penafsiran hermenetik terhadap al-Qur'an. Menurut Joseph N. Kickasola, dua pendekatan yang banyak digunakan adalah hermeunetika yang terbatas (the restrictive hermeneutic) dan hermetika yang luas (the expansive hermeneutic). Perspektif yang pertama banyak digunakan oleh Muslim militan-fundamental, sementara yang perspektif kedua banyak digunakan oleh Muslim moderat. Adakalanya kedua kelompok ini menggunakan satu ayat yang sama untuk menjelaskan pendapat yang bertolak bertolak belakang sama sekali. ${ }^{12}$

\footnotetext{
${ }^{10}$ Kebingungan-kebingan yang dihadapi oleh umat Islam terkait dengan hak-hak konstitusional inilah yang menjadi titik kunci Abdullahi Ahmed al-Naim untuk membangun suatu kerangka konseptual Syari'ah yang kompatibel dengan semangat zaman. Menurutnya, dengan tetap memaksakan fikih yang merupakan warisan masyarakat terdahulu sebagai pedoman hidup di masa sekarang, maka umat Islam justru akan mendapati kebuntuan. Namun di sisi yang lain, meninggalkan sama sekali syariat dan mengambil secara penuh peradaban modern (Barat) tidak pula menjawab keyakinan umat Islam tentang ke-memadai-an (sufficiency) Islam. Lihat: Abdullahi Ahmed al-Na'im, Dekonstruksi Syari'ah, (terj.) (Yogyakarta: LKiS, 2004), h. 14.

${ }^{11}$ Abdullahi Ahmed al-Na'im, "Syari'ah dan Isu-isu HAM", dalam Charles Kurzman, Liberal Islam: A Sourcebook, (terj.) (Jakarta: Paramadina, 2003), h. 370.

${ }^{12}$ Joseph N. Kickasola, The Clash of Civilizations Within Islam: The Struggle over the Qur'an between Muslim Democrats and Theocrats (USA: Grove City, April 5-6, 2006). Diakses dari http://www. visandvals.org/docs/The\%20Clash\%20of\%20Civilizations\%20WITHIN\%20Islam.pdf
}

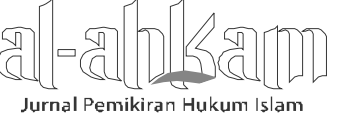

Volume 23, Nomor 2, Oktober 2013 
Perbedaan tersebut berangkat dari suatu konsep hermeunetika yang luas terhadap doktrin keagamaan. Kelompok ini juga menggunakan moral sebagai pondasi penafsiran, yang digunakan terutama untuk mengembangkan proyek kontekstualisasi hukum Islam (syari'ah) pada perubahan sosial masyarakat yang sedang dan selalu terjadi. Kontekstualisasi tersebut dimaknai sebagai suatu metode yang menjadikan konteks sebagai faktor penentu dan tujuan utama dari setiap makna teks yang tersurat dan teks-teks lain yang menjadi prinsip dasar sebagai penguat. Di samping itu, dalam memahami sumber-sumber ajaran Islam (seperti al-Qur'an dan sunnah), kelompok ini juga menggunakan prinsip moral fundamental sebagai acuan penafsiran, seperti keadilan, persamaan, musyawarah (shüra), ijmā' dan mașlahah, dengan menghidupkan kembali prinsip-prinsip dasar negara Madinah, seperti Piagam Madinah yang dibuat oleh Rasulullah dengan non-Muslim dhimmī (nonMuslim yang berada dan meminta perlindungan di wilayah Muslim).13

Salah satu tema penting yang menjadi fokus kajian kedua perspektif ini adalah masalah hak asasi manusia. Bagi kelompok moderat, adanya hak asasi manusia sebagai konsep dasar bukan menjadi suatu permasalahan yang rumit, karena pada prinsipnya, selagi itu baik dan memberikan kemaslahatan bagi manusia, dia juga pasti sesuai dengan agama Islam. Namun agak berbeda bagi kelompok puritan (fundamentalis-tradisionalis) yang kadangkala memandang hak asasi manusia sebagai bumerang bagi kejayaan dan ketinggian moral yang dibawa Islam dan alQur'an. Tak sedikit pula kelompok Islam puritan yang menolak secara penuh hak asasi manusia dan mengganggapnya tidak lebih produk kolonialisasi lanjutan dan imperialisme Barat terhadap dunia Muslim. ${ }^{14}$

\footnotetext{
${ }^{13}$ Beberapa contoh yang dapat disebutkan terkait dengan pendekatan moderat ini adalah Abdul Aziz Sachedina, The Islamic Roots of Democratic Pluralism (2001); Abdullahi Ahmed al-Naim, Toward an Islamic Reformation: Civil Liberties, Human Rights, and International Law (1990), Khaled Abou El-Fadl, Speaking in God's Name: Islamic Law, Authority and Women (2001), Islam and the Challenge of Democracy (2004), and The Great Theft: Wrestling Islam from the Extremists (2005); Louay M. Safi, The Challenge of Modernity: The Quest for Authenticity in the Arab World (1994); Stephen Schwartz, The Two Faces of Islam: The House of Sa'ud from Tradition to Terror (2002). Beberapa karya non-Muslim yang juga menggunakan perspektif ini di antaranya: John L. Esposito, The Islamic Threat: Myth or Reality (1995), Unholy War: Terror in the Name of Islam (2002); Noah Feldman, After Jihad: America and the Struggle for Islamic Democracy (2003); Paul Marshall, ed., Radical Islam's Rules: The Worldwide Spread of Extreme Shari'a Law (2005); Michael Novak, The Universal Hunger for Liberty: Why the Clash of Civilizations Is Not Inevitable (2004); Charles Kurzman, ed., Modernist Islam, 1840-1940: A Sourcebook (2002), Liberal Islam: A Sourcebook (1998). Lihat: Joseph N. Kickasola, The Clash of Civilizations Within Islam, h. 4.
}

${ }^{14}$ Lihat: Khaled Abou el-Fadhl, Selamatkan Islam dari Muslim Puritan, (terj.) Oakarta: Serambi, 2007).

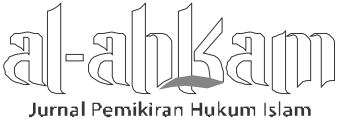


Adanya penolakan terhadap kebudayaan Eropa (Barat), termasuk doktrin hak asasi manusia, yang berangkat dari prasangka ini justru menjadikan identitas Islam "negatif" di mata Barat dan memunculkan sebuah efek domino berwujud ketakutanketakutan yang sebetulnya tidak juga berdasar dari masyarakat Barat terhadap komunitas Islam. Posisi vis a vis di antara kedua peradaban ini akhirnya memutuskan hubungan di antara keduanya, termasuk pula membangun etika hubungan internasional dalam hak asasi manusia. Meskipun tidak secara eksplisit ditujukan untuk "menentang" atau "menanggapi" hak asasi manusia internasional, memasuki paruh abad ke-20, terdapat karya-karya kaum intelektual Muslim terkait hak asasi manusia. Berangkat dari dua perspektif di atas (puritan dan moderat) karya-karya tersebut menggambarkan dua posisi yang berbeda. Di satu sisi terdapat karya yang meneguhkan kembali bahwa Islam memiliki konsep hak asasi manusia tersendiri dan tidak perlu menggunakan konsep Barat (Eropa) dan pada sisi yang lain terdapat pula karya yang berusaha untuk mencari titik temu di antara HAM Universal dan ajaran Islam. Dalam perjalanannya bahkan, muncul beberapa karya yang bernada "apologetis" dan memberikan sikap sinis kepada HAM Universal dan meyakini bahwa konsep HAM dalam Islam adalah paling utama dan sempurna.

Setelah Universal Declaration of Human Rights (UDHR) diumumkan oleh PBB pada tahun 1948, muncul pertanyaan dan perhatian serius di kelompok negaranegara Muslim, meskipun terdapat beberapa negara Muslim yang telah merdeka siap untuk masuk dan bergabung menjadi anggota PBB. Ketika Sidang Umum PBB mengumumkan UDHR, dua negara Muslim, Pakistan dan Arab Saudi berada pada sikap yang saling berhadap-hadapan terhadap isu tersebut. Pakistan secara kuat mendorong dan menerima Dokumen HAM tersebut, sementara Arab Saudi menolak untuk menandatangani, dengan alasan bahwa hukum Islam (syari'ah) telah lebih dulu dan cukup memadai untuk dijadikan pedoman dalam hak asasi manusia, laki-laki dan perempuan, sehingga UDHR tidak lagi dibutuhkan. ${ }^{15}$ Bahkan, dalam Konferensi yang dilakukan di Riyadh pada tanggal 22 Maret 1972 dijelaskan dua hal penting keberatan negara-negara Muslim terhadap Deklarasi HAM Universal, yaitu: pertama, dalam Islam, perempuan Muslim dilarang menikah dengan laki-laki non-Muslim. Bagi non-Islam, ini merupakan pelanggaran terhadap Pasal 16 UDHR, padahal larangan bagi perempuan untuk menikah dengan laki-laki

\footnotetext{
${ }^{15}$ Lihat: Abdullah al-Ahsan, "Law, Religion and Human Dignity in the Muslim World Today: al Examination of OIC's Cairo Declaration of Human Rights", dalam Journal of Law \& Religion, Vol. XXIV, h. 570 .
}

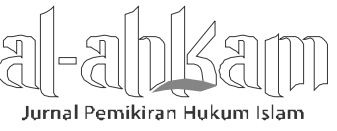


non-Muslim ditetapkan di dalam al-Qur'an. Kedua, larangan berpindah agama (dari Islam ke agama lain) dianggap bertentangan dengan Pasal 18 UDHR, padahal larangan berpindah agama dalam Islam (murtad) ditetapkan di dalam al-Qur'an. ${ }^{16}$

Puncak perdebatan ini, ketika UDHR telah dikukuhkan oleh PBB pada tahun 1948, dan pada tataran selanjutnya muncul dua kovenan kembar yang menjadi pengejawantah DUHAM bagi negara-negara dunia, serta beberapa kovenan yang dirumuskan sesuai dengan kebutuhan kala itu, ikatan organisasi negara-negara Muslim -yang dikenal dengan Organization Islamic Conference- justru membuat suatu Deklarasi HAM "tandingan” perspektif Islam di Kairo, yang dikenal dengan Deklarasi Kairo.

\section{Perkembangan HAM di Dunia Islam: Hak Asasi Manusia di Organisasi Kerjasama Islam (OKI)}

Menurut catatan Abdullah Ahsan, sebagaimana dikutip oleh Mashood A. Baderin, setelah konferensi tentang Hak Asasi Manusia dan Kebebasan dalam Islam di Nigeria pada tahun 1979, Konferensi ke-10 Menteri Luar Negeri OKI menyetujui pembentukan Komisi Musyawarah para pakar Muslim untuk menyusun rancangan dokumen hak asasi manusia Islam untuk OKI agar sesuai dengan komitmen organisasi pada Piagamnya tentang hak asasi manusia. ${ }^{17} \mathrm{Me}-$ masuki tahun 1980-an, OKI mulai berkonsetrasi memasukkan hak asasi manusia sebagai agenda konferensi mereka yang ditetapkan dalam Resolusi Hukum Dewan Menteri Luar Negeri.

Pada Konferensi Menteri Luar Negeri OKI yang ke-17 di Amman, Yordania, pada 1988, OKI mengeluarkan Resolusi No. 44/17-P tentang The Draft Document on Human Rights in Islam, yang di antara isinya mengakui tentang kebebasan, keadilan, perdamaian, persaudaraan dan persamaan di antara manusia, dan pengakuan terhadap hak asasi manusia sesuai dengan Syariat Islam. Secara lengkap Resolusi menyebutkan:

"Faithful to the immortal teachings of Islam concerning freedom, justice, peace, fraternity and equality among mankind, without any discrimination on the

\footnotetext{
16Dikutip dari Jaih Mubarok, Ijtihad Kemanusiaan di Indonesia (Bandung: Pustaka Bani Quraisy, 2005), h. 71.

17Mashood A. Baderin, Hukum Internasional HAM dan Hukum Islam, (terj.) Oakarta: Komnas HAM RI, 2007), h. 235.
} 
basis of race, colour or creed; Keenly aware of the dignity and rights to which all human beings are entitled according to the Islamic Shari 'a; Recognizing the importance of issuing a Document on Human Rights in Islam."18

Setelah rancangan dokumen ini terbentuk, Konferensi Menteri Luar Negeri menyerahkan dokumen ini kepada Kementerian Hukum negara-negara peserta untuk dilakukan pembahasan lebih lanjut dan proses finalisasi rancangan. Setelah itu, Konferensi Luar Negeri mengamanatkan kepada Sekretaris Jenderal OKI untuk membawa rancangan tersebut ke Pertemuan Kementerian Luar Negeri OKI. ${ }^{19}$

Setahun kemudian, pada Pertemuan ke-18 Menteri Luar Negeri, draft Deklarasi HAM kembali dimasukkan dalam salah satu rekomendasi Konferensi, dengan agenda mendorong Sekretariat Jenderal OKI untuk meninjau dan memberikan pandangan terkait dengan Draft yang telah disusun secepat mungkin, serta meminta Sekjen OKI untuk menerima dan mempertimbangkan Draft tersebut untuk dibicarakan dengan para pakar, serta mempersiapkan Draft final Deklarasi HAM untuk diajukan pada Konferensi Menteri Luar Negeri. ${ }^{20}$

Baru pada Konferensi ke-19 Menteri Luar Negeri OKI, yang diselenggarakan di Kairo, Republik Arab Mesir, dari tanggal 9 - 14 Muharrom 1411H (31 Juli-5 Agustus 1990) dengan tema Perdamaian, Interdependensi dan Pembangunan, Resolusi tentang Hak Asasi Manusia dalam Islam dikeluarkan oleh Konferensi, setelah sebelumnya dilakukan pemeriksaan ulang oleh Komite yang terdiri dari para pakar hukum di Teheran, dari 26 sampai 28 Desember 1989. Konferensi ini mengakui dan menetapkan, bahwa Deklarasi Kairo ditetapkan sebagai standard hak asasi manusia dalam Islam. ${ }^{21}$ Deklarasi dikeluarkan dengan Resolusi Tambahan No. 49/19-P tentang The Cairo Declaration on Human Rights in Islam. ${ }^{22}$ Deklarasi HAM Islam, yang dikenal dengan Deklarasi Kairo, menjadi pedoman bagi negara-negara Muslim

\footnotetext{
${ }^{18}$ Resolusi Menteri Luar Negeri OKI, Nomor 44/17-P on the Draft Document on Human Rights in Islam. The Seventeenth Islamic Conference of Foreign Ministers held in Amman, Hashemite Kingdom of Jordan from 3-7 Sha'bān 1408H (21-25 March, 1988).

${ }^{19}$ Resolusi Menteri Luar Negeri OKI, Nomor 44/17-P.

${ }^{20}$ Resolution No. 41/18-p on the Draft Document on Human Rights in Islam. The Eighteenth Islamic Conference of Foreign Ministers (Session of Islamic Fraternity and Solidarity), held in Riyadh, Kingdom of Saudi Arabia from 6-9 Sha'bān,1409H (13-16 March, 1989)

${ }^{21}$ Resolution No. 49/19-P on the Cairo Declaration on Human Rights in Islam. The Nineteenth Islamic Conference of Foreign Ministers (Session of Peace, Interdependence and Development), held in Cairo, Arab Republic of Egypt, from 9-14 Muharram 1411H (31 July to 5 August 1990).

${ }^{22}$ Annex to Res. No. 49/19-P The Cairo Declaration on Human Rights In Islam.
}

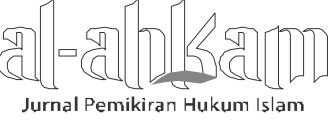


terkait isu-isu hak asasi manusia, karena selain didasarkan pada ayat-ayat al-Qur'an, Deklarasi ini memperhatikan "rambu-rambu" Syariat Islam yang telah diakui pula oleh komunitas Islam di seluruh dunia. ${ }^{23}$

Hampir sewindu berjalan pasca Deklarasi Kairo disahkan, OKI baru kembali membuka perbincangan tentang isu-isu HAM dalam Konferensi, terutama oleh Konferensi Menteri Luar Negeri. Memasuki abad ke-21, muncul dorongan beberapa negara Muslim untuk mengembangkan suatu sistem masyarakat yang toleran, dipenuhinya kebebasan fundamental, adanya pemerintahan yang bersih, penegakan hukum, akuntabilitas, keterbukaan dan dialog dengan sesama penganut agama lain, serta upaya untuk menolak fasisme dan menguatkan kebanggaan individu atas identitas Muslimnya, yang pada akhirnya menguatkan negara-negara yang tergabung di dalam OKI untuk membuka kembali lembaran wacana hak asasi manusia.

Selanjutnya, ketika Konferensi OKI diselenggarakan di Sudan tahun 2002, salah satu Resolusi Menteri Luar Negeri mengangkat kembali Deklarasi Kairo dan menyadari untuk mempromosikan dan melindungi hak asasi manusia yang diakui secara universal, meskipun juga harus mempertimbangkan latar belakang budaya, agama, kondisi nasional dan regional sebagai suatu kekhususan, serta memperhatikan Deklarasi HAM Kairo. ${ }^{24}$

Adanya niat baik dari kelompok Islam untuk menjadikan hak asasi manusia sebagai landasan moral hubungan antar negara-negara dunia merupakan suatu kemajuan yang sangat positif, meskipun jika diamati latar belakang munculnya semangat tersebut tidak luput dari adanya anggapan/tuduhan negatif sementara kelompok (terutama dunia Barat) tentang Islam. Islamfobia, demikian istilah yang kerapkali ditemui di beberapa Resolusi OKI, menjadi salah satu pendorong kuat bagi negara-negara anggota OKI untuk memberikan citra yang baik tentang Islam kepada Barat. ${ }^{25}$ Di samping itu, desakan secara politik, baik langsung atau tidak, dari PBB kepada OKI terutama dalam hal perlindungan hak asasi manusia menjadi

\footnotetext{
${ }^{23}$ Lihat: Abdullah al-Ahsan, "Law, Religion and Human Dignity in the Muslim World Today, h. 570.

${ }^{24}$ Pembukaan Resolution No. 2/29-LEG, on the Follow-up of the Cairo Declaration on Human Rights in Islam, Khartoum, Republic of the Sudan 14-16 Rabī' al-Thānī, 1423H/25-27 June, 2002.

25 Mengatasi fenomena "Islamfobia" ini, OKI bahkan menjadwalkan suatu peninjuan tersendiri terhadap Islamfobia setiap tahunnya. Di dalam tinjauan tersebut, dilaporkan tentang hal-hal yang menjadi ketakutan atau kekhawatiran masyarakat Bara (Eropa) terhadap Islam. Lihat: http:// www.oic-oci.org/ page_detail.asp?p_id=182
} 
salah satu pendorong bagi OKI untuk menjadikan HAM sebagai standar nilai yang harus pula diterapkan oleh negara-negara OKI.26

OKI kemudian mulai mendorong kerja sama antara OKI dan PBB terkait dengan isu-isu hak asasi manusia. Di antara yang cukup signifikan adalah pada 1998 OKI dan PBB bekerja sama mengadakan seminar yang membahas tentang "Memperkaya Universalitas HAM: Perspektif Islam tentang Hak Asasi Manusia”, ${ }^{27}$ sebagai bagian dari kegiatan untuk merayakan Peringatan ke-50 Tahun UDHR. Kemudian, Pidato Sekjen OKI pada Sesi ke-56 dari Komisi tentang Hak Asasi Manusia pada tahun 2000, menyebutkan, bahwa penting kiranya untuk mengakhiri semua pelanggaran terang-terangan hak asasi manusia sehingga semua penduduk dunia bisa menikmati hak yang sama akan pendidikan, kesehatan, pembangunan, dan kesejahteraan dalam suatu lingkungan santun bermoral, melalui pemberantasan kemiskinan, kesengsaraan, kelaparan, kebutahurufan, dan sebagainya. ${ }^{28}$ Untuk itu pula, demikian lanjutan dari pidato ini, Sekjen OKI yakin bahwa aspek-aspek tersebut dapat dicapai melalui kerja sama internasional antar negara-negara yang ada di dunia, sembari menghormati adat istiadat dan kebudayaan masing-masing.

Memasuki abad ke-21, pembahasan isu HAM di OKI semakin mengalami kemajuan signifikan. Hal ini ditandai dengan adanya Resolusi-resolusi Bidang Hukum Pertemuan Dewan Menteri Luar Negeri OKI. Sejak tahun 2000, OKI mengeluarkan Resolusi yang membahas tentang HAM, baik secara umum atau dalam rangka menindaklanjuti Deklarasi HAM Kairo. Di antaranya adalah Resolusi No. 2/29-LEG on the Follow-Up of the Cairo Declaration on Human Rights in Islam, di Khartoum, Republik Sudan pada 14-16 Rabī' al-Thānī 1423H/ 25-27 Juni 2002, Resolusi No. 2/30-LEG di Iran 28-30 Mei 2003, Resolution No. 3/30-LEG tentang Coordination among Member States in the Field of Human Rights, Resolusi No. 2/31LEG dan Resolusi No. 2/31-LEG di Turki pada 14-16 Juni 2004, Resolusi No. 1/32LEG Tahun 2005 tentang Human Rights, Resolusi No. 1/33-LEG Tahun 2006 di

\footnotetext{
${ }^{26}$ Lihat dalam, Resolution No. 3/29-Leg on Coordination Among Member States in the Field of Human Rights; lihat pula, Resolusi Komisi HAM PBB No. 1999/82 tentang Defamation of Religions (30 April 1999), yang secara tersirat memuat posisi Islam yang sering diidentikkan dengan pelanggaran "kebebasan beragama" dan hak asasi manusia.

${ }^{27}$ Dalam Resolusi Komisi HAM PBB No. 1999/82 tentang Defamation of Religions (30 April 1999), PBB memberikan apresiasi kepada OKI yang telah berupaya memajukan dan mendorong pembangunan hak asasi manusia.
}

${ }^{28}$ Mashood A. Baderin, Hukum Internasional HAM dan Hukum Islam, h. 236. 
Azerbaijan, Resolusi No. 2/34-LEG Tahun 2007 tentang Human Rights, dan Resolusi No. 2/35-LEG Tahun 2008. Beberapa resolusi yang disebutkan di atas merupakan follow-up dan upaya koordinasi negara OKI dalam bidang HAM yang juga dapat dijadikan sinyalemen meningkatnya perhatian negara-negara Muslim terhadap permasalahan HAM.

Pada Resolusi tahun 2009, Konferensi Menteri Luar Negeri OKI Bidang Hukum telah membahas tentang pembentukan Komisi HAM Independen untuk OKI. Rencana tersebut didasarkan pada rekomendasi yang dikeluarkan oleh Extra-ordinary Islamic Summit Conference ke-3 di Makkah al-Mukarramah pada Desember 2005, bahwa OKI dimungkinkan untuk membentuk Komisi HAM yang bersifat independen untuk mendorong penegakan dan perlindungan HAM di negara-negara OKI. ${ }^{29}$

Di samping itu, keinginan untuk membentuk Komisi HAM OKI ini telah pula diawali pula dengan perubahan Piagam OKI (Charter of the Organisation of the Islamic Conference) pada 7 Rabī' al-Awwal 1929 H/14 Maret 2008 M di Kota Dakar, Republik Senegal. Dalam Pembukaan Piagam OKI tersebut disebutkan, bahwa OKI akan mendorong dan menghidupkan nilai-nilai luhur dalam Islam yang berhubungan dengan perdamaian, kasih sayang, toleransi, persamaan, keadilan, dan kehormatan manusia. ${ }^{30}$ Piagam ini juga menandai reformasi yang dilakukan OKI secara internal dan mengarah pada sebuah organisasi internasional yang lebih membuka diri untuk bekerja sama dengan aktor-aktor internasional lainnya, baik secara bilateral maupun dalam forum multilateral.

Dalam Pasal 5 Piagam ini disebutkan bahwa OKI terdiri dari beberapa lembaga inti, salah satunya adalah Independent Permanent Commission of Human Rights atau disingkat IPHRC. Dalam Bab X Pasal 15 Piagam OKI hasil perubahan di Dakkar, Senegal, dijelaskan lebih lanjut tentang IPHRC ini, yaitu bahwa IPHRC akan mempromosikan hak asasi manusia dalam bidang hak sipil politik, hak sosial, dan ekonomi diabadikan dalam dokumen-dokumen kovenan dan deklarasi secara universal, berdasarkan instrumen hak asasi manusia dan nilai-nilai Islam. ${ }^{31}$

\footnotetext{
${ }^{29}$ Secretary General's Report, New Vision for the Muslim World: Solidarity in Action Presented at the Third Extraordinary Session of the Islamic Summit Conference, Makkah al-Mukarramah, 7-8 December 2005.

30Pembukaan Piagam OKI. Diakses dari http:/ /www.oic-oci.org/is11/english/Charter-en.pdf

31Pasal 5 dan 15 Piagam OKI; Lihat pula, Abdullah al-Ahsan, "Law, Religion and Human Dignity in the Muslim World Today", h. 572.
} 
Pertemuan Menteri Luar Negeri OKI ke-38 di Astana, Kazakhstan, pada 28-30 Juni 2011, menjadi pertanda baru fase perkembangan HAM di Negara-negara Muslim. Dalam pertemuan ini, OKI mengadopsi sebuah Resolusi No. 2/38-LEG Tentang "The Establishment of the OIC Independent Permanent Human Rights Commission (Statute of IPHRC)"32 yang menegaskan pembentukan IPHRC dan sekaligus pula memilih 18 orang Anggota Komisi. Berdasarkan Resolusi yang lain, ${ }^{33}$ pertemuan ini kemudian memilih 18 orang Anggota Komisi IPHRC, yang mewakili 3 kawasan negara-negara Anggota OKI yang berjumlah lima negara, yaitu: kawasan Asia, Arab, dan Afrika.

\section{Gambaran Singkat tentang Komisi HAM OKI}

Gambaran tentang Komisi HAM OKI dapat dirujuk pada Statuta IPHRC yang telah diadopsi pada tahun 2011. Statuta ini menjadi dokumen utama pendirian dan fungsi yang dijalankan oleh Komisi. Untuk lebih lanjut mengetahui tentang IPHRC tersebut, artikel ini akan mengulas sedikit tentang Statuta dan kaitannya dengan peranan IPHRC dalam pembangunan dan perlindungan HAM di negara-negara Muslim.

\section{Anggota Komisi, Independensi dan Sekretariat}

IPHRC terdiri dari 18 orang anggota yang dipilih dari para ahli dalam bidang HAM dari Anggota Negara OKI melalui pertemuan Dewan Kementerian Luar Negeri OKI untuk masa waktu tiga tahun secara bergantian. ${ }^{34}$ Keterwakilan ini bersifat independen dan atas nama pribadi (bukan atas nama negara), sehingga secara normatif, para anggota Komisi tersebut bekerja secara independen di luar dari kendali dan kontrol pemerintah negara asalnya. Di samping itu, Statuta IPHRC juga mendorong adanya nominasi dari perempuan untuk menjadi anggota Komisi, sebagaimana ditegaskan di dalam Pasal 6 Statuta.

Dalam melaksanakan kewajibannya, IPHRC dibantu oleh suatu Sekretariat Komisi, yang dipimpin oleh Direktur Adminsitratif yang ditunjuk oleh Sekretaris Jenderal OKI, dengan mengacu kepada hasil konsultasi dan musyawarah negara-

\footnotetext{
${ }^{32}$ Resolution No. 2/38-LEG tentang "The Establishment of the OIC Independent Permanent Human Rights Commission" (selanjutnya disebut Statuta IPHRC), diakses dari http://www.oicoci.org/38cfm/en/documents/res/LEG-RES-38-CFM-FINAL-2.pdf

${ }^{33}$ Yaitu Resolusi No. 7/38-ORG on Election of Members of the OIC Independent Permanent Human Rights Commission.

${ }^{34}$ Pasal 2 Statuta IPHRC.

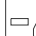

Jurnal Pemikiran Hukum Islam 
negara anggota OKI. ${ }^{35}$ Saat ini, Negara-negara OKI telah memutuskan bahwa Sekretariat Komisi terletak di Jeddah, Saudi Arabia, dan Sekretariat bertugas untuk mendukung kerja-kerja IPHRC dalam menjalankan mandat dan fungsinya di bidang HAM.

\section{Perhatian Hak-hak oleh Komisi}

Disebutkan di dalam Statuta IPHRC, bahwa IPHRC memiliki peranan dalam memajukan HAM dan mendorong perhatian negara-negara Muslim untuk mengkonsolidasikan peradaban Islam dan nilai-nilai moral Islam. Komisi juga berperan dalam membuka dialog antar peradaban terkait dengan isu-isu HAM, dengan mengacu dan konsisten pada Piagam OKI. ${ }^{36}$ Mengacu pada Pasal 8 Statuta tersebut, dapat dipahami, bahwa selain berpedoman pada Deklarasi Universal HAM dan Deklarasi Kairo, IPHRC juga akan merujuk pada peradaban Islam yang telah tumbuh dalam rentang sejarah untuk kemudian membangun suatu dialog antar peradaban dunia dalam isu-isu HAM. Dalam hal ini pula kemudian IPHRC menjadi sebuah badan yang bersifat dialogis secara internal, membuka peluang diskusi dan dialog lebih lanjut tentang permasalahan-permasalahan HAM yang terjadi di Negara-negara Muslim, ataupun hubungannya dengan organisasi dan badan-badan HAM di luar OKI. ${ }^{37}$

Di samping itu, IPHRC juga mendorong setiap Negara anggota OKI untuk mengkonsolidasikan hak-hak sipil, politik, ekonomi, sosial dan budaya, serta bekerja sama dengan negara-negara anggota untuk menjamin penguatan dan perlindungan hak-hak tersebut. Badan HAM ini juga diberikan fungsi untuk meninjau "kepatuhan" negara-negara Muslim yang tergabung di dalam OKI terhadap hak asasi manusia, serta mendorong secara politis negara-negara tersebut untuk memajukan HAM dalam ranah kebijakan, terutama dalam pemajuan hak-hak perempuan, anak-anak dan mereka yang memiliki kebutuhan khusus (kelompok rentan), di bidang ekonomi, sosial, politik dan budaya, serta penghapusan segala bentuk kekerasan dan diskriminasi.

The Commission shall support the Member States' efforts to consolidate civil, political, economic, social, and cultural rights (Article 9). The Commission shall

\footnotetext{
35 Pasal 22 Statuta OIC IPHRC.

36 Pasal 8 Statuta IPHRC

37Terkait dengan hal ini, lihat Laporan Pemantauan Sesi Pertama Sidang IPHRC (Jakarta: HRWG, 2012).
} 
cooperate with the Member State to ensure consolidation of civil, political, economic, social, and cultural rights in the Member States in accordance with the OIC Charter and to monitor observance of the human rights of Muslim communities and minorities (Article 10). The Commission shall support the Member States' efforts in terms of political aimed at enhancing legislation and policies and in favour of advancing the rights of women, the young and those with special needs, in the economic, social, political and cultural fields as well as eliminating all forms of violence and discrimination (Article 11). ${ }^{38}$

\section{Mandat dan Fungsi IPHRC}

Mandat dan fungsi IPHRC secara spesifik dijelaskan dalam Pasal 12 sampai 17 Statuta, yang dengan mandat-mandat tersebut IPHRC dapat memainkan peranannya dalam pemajuan dan perlindungan di negara-negara OKI atau hubungannya dengan aktor-aktor internasional lainnya, baik secara bilateral ataupun dalam forum multilateral. Dari pasal-pasal tersebut, mandat dan fungsi IPHRC tersebut dapat dirinci berikut ini: pertama, Komisi HAM OKI menjalankan fungsi konsultatif dan menyampaikan rekomendasi kepada Dewan (Menteri Luar Negeri). IPHRC dapat pula melaksanakan tugas yang diberikan oleh Konferensi Islam Tingkat Tinggi atau Dewan Menteri Luar Negeri. Kedua, Komisi diberi mandat untuk mendukung posisi OKI dalam bidang HAM di tingkat internasional dan mengkonsolidasikan kerja sama antar negara anggota OKI dalam bidang tersebut. Ketiga, Komisi diberi mandat untuk melakukan kerja sama secara teknis di bidang HAM dengan negara-negara anggota dan melakukan peningkatan kesadaran terhadap HAM, serta menawarkan konsultasi kepada negara anggota pada isu-isu HAM. Keempat, tidak hanya mendorong peranan Pemerintah dalam mempromosikan dan mendorong HAM, Komisi juga dimandatkan untuk mendorong organisasi masyarakat sipil yang aktif dalam isu-isu HAM, termasuk pula meningkatkan kerja sama antar organisasi dan lembaga internasional atau regional di bidang HAM. ${ }^{39}$ Kelima, Komisi dapat melakukan penelitian atau studi tentang isu-isu yang terkait dengan HAM, termasuk di dalamnya adalah isu-isu yang disampaikan dalam pertemuan Dewan Menteri Luar Negeri, hasil koordinasi dan pertukaran informasi di antara organisasi dan lembaga lainnya, baik pada tingkat internasional ataupun regional dalam bidang HAM. ${ }^{40}$ Keenam, Komisi dapat bekerja sama dengan negara anggota OKI yang mengajukan permintaan kepada Komisi, dalam upaya perluasan

\footnotetext{
38Pasal 9-11 Statuta IPHRC

${ }^{39}$ Pasal 15 Statuta IPHRC

40 Pasal 16 Statuta IPHRC

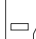

Jurnal Pemikiran Hukum Islam
} 
dan diseminasi instrumen HAM, mengajukan rekomendasi mengenai penyempurnaan Deklarasi HAM OKI dan perjanjian-perjanjian lain, serta menyarankan ratifikasi perjanjian dan instrumen HAM OKI yang selaras dengan nilainilai Islam dan sesuai dengan standar internasional. ${ }^{41}$

Dari mandat tersebut, IPHRC kemudian menetapkan beberapa program prioritas yang dilaksanakan, di antaranya adalah terkait dengan hak-hak perempuan dan anak, hak atas pembangunan, memerangi Islamofobia dan ajaran kebencian berdasarkan agama/keyakinan, permasalahan Rohingya, dan sebagainya. Dengan ini pula kemudian IPHRC membentuk tim kerja (working group) yang bertugas untuk menyusun agenda dan melaksanakan program-program yang telah direncanakan.

\section{Deklarasi HAM Universal dan Deklarasi HAM Kairo}

Sebagaimana dijelaskan di atas, kemunculan Deklarasi Kairo tidak luput dari terbentuknya Universal Declaration of Human Rights (UDHR) pada tahun 1948 oleh PBB. Meskipun tidak begitu signifikan, tetapi penolakan (sikap abstain) yang disampaikan oleh beberapa negara Muslim menjadi titik awal pembentukan Deklarasi Kairo dan relasi yang tak begitu harmonis di antara komunitas Islam dan HAM itu sendiri. Dalam hal ini, penulis tidak akan menjelaskan lebih lanjut tentang rincian hak yang dicantumkan di dalam Deklarasi Kairo.

Di samping hal tersebut, negara-negara Muslim dan negara-negara Timur Tengah secara lebih khusus, berada pada situasi yang dilematis dalam hal penegakan dan pelaksanaan hak asasi manusia. Di satu sisi komunitas Muslim "enggan" menerima prinsip universalitas HAM karena dipandang bertentangan dengan nilai-nilai Islam, namun di sisi lain mereka merasa perlu untuk menunjukkan bahwa Islam juga menghargai HAM, karena kuatnya justifikasi moral yang dimiliki HAM itu sendiri dalam relasinya antar negara. ${ }^{42}$ Hal inilah yang, setidaknya, menjadi jawaban mengapa negara-negara yang tergabung dalam OKI pada tahun 1990-an mengadopsi Deklarasi Kairo dan "seakan-akan" tidak mengakui DUHAM sebagai landasan universal HAM di seluruh dunia.

Sehubungan dengan universalitas HAM, dalam catatan Heidi Morrison, apabila merujuk pada Pembukaan UDHR dan Pembukaan Deklarasi Kairo tentang HAM

\footnotetext{
41Pasal 17 Statuta IPHRC

42 "Human Rights in Arab Countries", http:/ /www.al-bab.com/arab/human.htm
} 
dalam Islam dapat dikatakan keduanya berada dalam suatu wacana yang sama dan sama-sama mengklaim berbicara atas nama semua umat manusia dan membawa visi universalitas. Namun di sisi yang lain, menurut Morrison pula, kedua pembukaan Deklarasi tersebut, termasuk pula pasal-pasal yang termaktub di dalamnya, mengungkap gagasan yang agak berbeda tentang apa yang dimaksud dengan universalitas itu sendiri, ${ }^{43}$ karena apabila dilihat dari sisi historis asal usul keduanya, legitimasi yang dimilikinya, serta relevansinya dalam praktik, istilah "universal" itu sendiri pada dasarnya tidak berorientasi universal. ${ }^{44}$ Dalam tulisannya yang singkat, Morrison memberikan suatu kesimpulan, bahwa kedua Deklarasi ini sama-sama mengklaim universalitasnya, meskipun sebetulnya keduanya juga tidak bersifat universal. Dengan kata lain, universalitas bukanlah sebuah fakta, tetapi suatu proyek politik yang tertanam dalam rentang sejarah dunia, ${ }^{45}$ sehingga klaim universalitas itu dapat saja dilakukan oleh siapapun dan sangat tergantung dengan kekuatan politik yang dimilikinya.

Dengan pandangan Morisson di atas, tulisan ini tidak pula bermaksud untuk menegasikan sisi universalitas HAM ataupun kedua Deklarasi tersebut di atas. ${ }^{46}$ Adalah menarik untuk meninjau bagaimana para Anggota Komisi HAM OKI memandang kedua Deklarasi HAM Kairo yang telah dirumuskan pada tahun 1990 tersebut, apalagi setelah kemunculannya ada banyak kritik yang dilontarkan oleh komunitas internasional terhadap Deklarasi ini karena dianggap tidak sesuai dengan prinsip-prinsip HAM yang lebih dulu telah disepakati oleh komunitas internasional.

Setelah dibentuk pada tahun 2011, IPHRC mengadakan dua kali pertemuan setiap tahunnya, pertama kali di Jakarta pada Februari 2012. Salah satu tema yang dibahas dalam pertemuan-pertemuan ini adalah tentang landasan normatif

\footnotetext{
${ }^{43}$ Heidi Morrison, "Beyond Universalism”, dalam Muslim World Journal of Human Right, Volume 1, Issue 1 (October 2004), http://www.bepress.com/mwjhr/vol1/iss1/art2

${ }^{44}$ Lihat lebih lanjut dalam, Heidi Morrison, "Beyond Universalism”, h. 12-13.

${ }^{45}$ Heidi Morrison, "Beyond Universalism", h. 17; Bandingkan dengan Elizabeth Ann Mayer, "Debating the Universality of Human Rights; A Plea for a Critical Perspective", diakses dari http:/ /gst.wharton.upenn.edu/mayera/documents/Hamudps3.pdf

46 Menjembatani diskusi tentang universalitas HAM tersebut, beberapa ahli membedakan antara "universalitas" dan "universalisme" HAM, yang keduanya memiliki konsep yang berbeda. Universalitas HAM berarti pada sifat penerimaan yang universal atau mendunia atas ide HAM, sedangkan universlisme HAM berkaitan dengan penafsiran dan penerapan HAM. Keduanya memiliki arti yang mirip, namun berbeda, karena dalam universalitas yang ditekankan adalah tatanan moral dan norma yang ada di dalam HAM dan diakui dan dikukuhkan oleh seluruh dunia, sementara di dalam universalisme yang muncul adalah politisasi HAM dalam penerapannya oleh negara-negara besar.
}

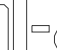

Jurnal Pemikiran Hukum Islam 
penerapan HAM yang digunakan oleh Komisi, termasuk di dalamnya adalah Deklarasi HAM Kairo. Dalam pada itu, Anggota Komisi berada pada suatu kesimpulan bahwa Deklarasi Kairo merupakan sebuah capaian yang patut diapresiasi sebagai upaya negara-negara Muslim untuk mengakui keberadaan HAM. Namun di sisi yang lain, terutama terkait dengan norma-norma yang banyak mendapatkan kritik dari luar dan dianggap tidak sesuai dengan prinsip-prinsip HAM internasional, IPHRC menganggap perlu untuk meninjau pasal-pasal tersebut untuk kemudian disempurnakan.

Secara spesifik di dalam Deklarasi Kairo, suatu hal yang muncul dalam pertemuan IPHRC tersebut, yaitu tentang batasan syari'ah yang ditetapkan oleh Deklarasi HAM. Dengan latar belakang yang berbeda, baik secara historis, budaya ataupun tradisi hukum Islam, negara-negara Anggota OKI memiliki pandangan dan perspektif yang berbeda-beda terkait dengan penerapan Syariat Islam, baik dalam ranah teologis ataupun di ranah fikih. Hal ini juga semakin rumit ketika muncul sejumlah kajian dan studi para intelektual Muslim kontemporer tentang apa yang kemudian dimaksud dengan Syariat itu sendiri. Dengan demikian, diskusi anggota IPHRC ini kemudian menyepakati bahwa pada dasarnya agak sulit untuk menyeragamkan pandangan-pandangan negara-negara OKI tentang Syariat itu, apalagi Syariat yang dimaksud juga memasukkan aspek-aspek hukum Islam. Keragaman penerapan hukum Islam tentu menjadi kendala tersendiri bagi negaranegara OKI untuk memiliki pandangan yang sama terkait dengan isu hukum Islam tertentu dan HAM. 47

Dalam hal ini, pelaksanaan Deklarasi Kairo dilaksanakan secara pragmatis oleh Komisi HAM OKI demi pembangunan dan perlindungan HAM di Negara-negara anggota OKI secara meluas. Pelaksanaan pragmatis ini mengarah pada pelaksanaan dan penggunaan norma-norma HAM yang terdapat di dalam Deklarasi Kairo dan menunda pelaksanaan norma-norma yang selama ini diperdebatkan. Dengan demikian, IPHRC sebagai Komisi HAM OKI yang diberikan mandat untuk memajukan perlindungan HAM di Negara-negara Anggota OKI tidak harus berhenti pada perdebatan konseptual tentang HAM, namun dapat melaksanakan upayaupaya perbaikan situasi HAM di negara-negara OKI yang masih banyak mendapatkan rapor merah dalam penegakan HAM.

\footnotetext{
${ }^{47} \mathrm{Hal}$ ini didasarkan pada pemantauan dan observasi penulis pada saat Sidang Pertama IPHRC di Jakarta, pada 20 - 25 Februari 2012, terutama pada saat sesi diskusi terbuka antar anggota IPHRC. 


\section{Prospek Komisi HAM OKI}

Sebagai suatu organisasi terbesar kedua setelah Perserikatan Bangsa-Bangsa (PBB), OKI memiliki potensi besar dalam merealisasikan kemajuan peradaban umat manusia, termasuk pula di dalamnya adalah kemajuan dan perlindungan HAM. Arus utama HAM internasional pun tengah mendorong mekanisme regional/multilateral terkait dengan badan HAM yang diharapkan mampu mendorong penegakan HAM lebih progresif, sesuai dengan standar-standar internasional yang telah disepakati.

Secara historis dalam kancah politik internasional, OKI cukup unik apabila dilihat status keberadaannya sebagai komunitas negara-negara Muslim. Dengan membawa solidaritas keagamaan, pada perkembangannya, OKI mampu memberdayakan negara-negara Muslim untuk membangun sebuah peradaban bersama, meskipun pada paroh pertama kemunculannya — dan merupakan hal utama yang menjadi sebab pendiriannya- OKI banyak berkonsentrasi pada isu-isu pembebasan Palestina, selain pula secara "dingin" OKI menanamkan politik konfrontatif kepada komunitas Barat. Dalam hal inilah kemudian muncul beragam spekulasi bahwa telah terjadi pertentangan di antara dua peradaban besar, kelompok Islam dihadap-hadapkan dengan kelompok Barat.

Seiring dengan perkembangan zaman dan semakin tingginya relasi antar negara, yang berimplikasi pada keterbukaan sikap negara-negara Muslim secara khusus, OKI mulai berbenah diri untuk lebih terlibat dalam arena antar negara di tingkat internasional, seperti keterlibatan aktifnya di Dewan HAM PBB dan Sidang Umum PBB. Setidaknya, OKI menjadi salah satu fraksi politik yang diperhitungkan di kancah internasional. Sikap tersebut tentu disambut oleh masyarakat internasional, karena sebelumnya negara-negara Muslim seringkali eksklusif dari pergaulan internasional, terutama yang berkaitan dengan isu-isu kontemporer, seperti HAM dan demokrasi. Dalam pada itu, secara institusional OKI juga telah mereformasi diri, berupaya untuk menanggalkan sisa-sisa eksklusivitas masa lalu, meminimalisasi egosentris keagamaan, serta bernegosiasi dengan peradaban modern yang tengah berlangsung di hampir seluruh belahan dunia, tanpa harus melepaskan identitas diri sejak organisasi ini didirikan.

Adanya reformasi di tubuh OKI, yang ditandai dengan perubahan Piagam OKI dan tersusunnya The OIC Ten Year Action, juga menjadi titik berangkat pembangunan dan perlindungan HAM di negara-negara Muslim, setelah hampir 
dua dasawarsa tidak terdengar lagi kabarnya tatkala OKI mengeluarkan Deklarasi HAM Kairo. Dengan kemajuan ini, ditambah pula telah terpilihnya wakil Indonesia sebagai salah satu dari 18 Anggota Komisioner IPHRC, pembangunan dan perlindungan HAM melalui OKI sangat relevan dengan kepentingan nasional Indonesia, karena selain sebagai negara berpenduduk Muslim terbesar di dunia, Indonesia relatif lebih maju dibandingkan dengan negara-negara Muslim lainnya dalam wacana demokrasi, penegakan hukum, dan HAM. Dalam hal ini pula IPHRC harus disambut secara baik oleh komunitas Muslim dan Indonesia secara khusus, karena apabila tidak, alih-alih untuk menjadikan OKI sebagai pendulum perlindungan HAM di negara-negara Muslim, Komisi HAM ini justru hanya menjadi badan-badan normatif yang tidak berpengaruh sama sekali pada peradaban umat manusia. Jika ini terjadi, maka persangkaan bahwa negara-negara Islam hanya mengikuti dan reaktif terhadap peradaban Barat adalah benar adanya, karena asumsi dasar negara-negara OKI membentuk Komisi hanya sebatas "pencitraan" untuk meng-counter serangan dan desakan dari negara-negara Barat. Dengan itu, pembentukan IPHRC harus pula dilihat sebagai titik tolak pembuktian konkret suatu tesis apakah negara-negara Muslim betul-betul mereformasi diri untuk lebih meningkatkan pembangunan dan perlindungan HAM di negara masing-masing atau masih terjebak pada egosentris keagamaan.

\section{Kesimpulan}

Berdasarkan uraian singkat di atas, tentu pertanyaan muncul adalah bagaimana masa depan Komisi HAM Independen yang dibuat oleh OKI dalam pembangunan isu HAM di dunia pada masa yang akan datang dan secara khusus di komunitas Muslim? Apakah IPHRC akan menjadi wadah dialogis di antara ragam perdebatan HAM dan hukum Islam atau justru sebaliknya IPHRC justru memperuncing diskursus HAM dan hukum Islam yang semakin merekahkan pandangan dikotomis.

Untuk itu pula kemudian dialog setara yang terus-menerus antara dua entitas, hukum Islam (syariat) dan HAM harus selalu menjadi perhatian semua kalangan untuk membuka peluang yang lebih luas pada pemahaman bersama dan pada gilirannya akan memudahkan tercapainya kemajuan dan perlindungan HAM itu sendiri. Di sisi lain, dialog ini menjadi sarana penting bagi pembangunan diskursus HAM dan menghilangkan stigma negatif terhadap hukum Islam yang seringkali dituduh melanggar HAM, serta sebaliknya membuka ruang interpretasi dan kajian 
hukum Islam yang secara terus-menerus mengarah pada relevansi hukum Islam dalam kehidupan kontemporer.[a]

\section{DAFTAR PUSTAKA}

al-Ahsan, Abdullah, "Law, Religion and Human Dignity in the Muslim World Today: An Examination of OIC's Cairo Declaration of Human Rights", dalam Journal of Law \& Religion, Vol. XXIV.

Annex to Res. No. 49/19-P The Cairo Declaration on Human Rights In Islam.

Azra, Azyumardi, Pergolakan Politik Islam: Dari Fundamentalisme, Modernisme, Hingga Pos-modernisme, Jakarta: Paramadina, 1996.

Baderin, Mashood A., Hukum Internasional HAM dan Hukum Islam, (terj.), Jakarta: Komnas HAM RI, 2007.

Chaider S. Bamualim, dkk., Islam and The West, Jakarta: Konrad Adenauer Stiftung \& Center for Languages and Cultures, 2003.

el-Fadhl, Khaled Abou, Selamatkan Islam dari Muslim Puritan, (terj.), Jakarta: Serambi, 2007.

Hadi, Parni, "Media and the Politic of Image Making", dalam Islam and The West,

Hitti, Philip K., The History of Arabs, (terj.), Jakarta: Serambi, 2008.

Hourani, Albert, Arabic Thought in the Liberal Age: 1798-1939, London: Cambridge University Press, 1983.

Huntington, Samuel P., "The Clash of Civilization?", dalam Foreign Affairs, Vol. 72, No. 3, Summer, 1993.

Huntington, Samuel P., The Clash of Civilization and the Remaking of World Order, New York: Simon and Schuster, 1996.

Inglehart, Ronald, dan Pippa Norris, "The True Clash of Civilization" dalam Foreign Policy, No. 135, (Mar. - Apr), 2003.

Kickasola, Joseph N., The Clash of Civilizations Within Islam: The Struggle over the Qur'an between Muslim Democrats and Theocrats, USA: Grove City, April 5 6, 2006.

Kurzman, Charles, (ed.), Modernist Islam, 1840-1940: A Sourcebook, 2002.

Kurzman, Charles, Liberal Islam: A Sourcebook, (terj.), Jakarta: Paramadina, 2003.

Laporan Pemantauan Sesi Pertama Sidang IPHRC, Jakarta: HRWG, 2012.

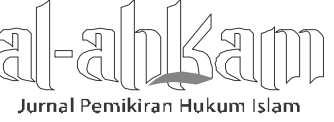

Volume 23, Nomor 2, Oktober 2013 
Muhammad Hafiz

Mubarok, Jaih, Ijtihad Kemanusiaan di Indonesia, Bandung: Pustaka Bani Quraisy, 2005.

al-Na'im, Abdullah Ahmed, Islam and Secular State.

al-Na'im, Abdullahi Ahmed, "Syari'ah dan Isu-isu HAM", dalam Liberal Islam: $A$ Sourcebook

al-Na'im, Abdullahi Ahmed, Dekonstruksi Syari'ah, (terj.), Yogyakarta: LKiS, 2004.

Pembukaan Resolution No. 2/29-LEG, on the Follow-Up of the Cairo Declaration on Human Rights in Islam, Khartoum, Republic of the Sudan 14-16 Rabì' alThānī, 1423H/25-27 June, 2002.

Resolusi Komisi HAM PBB No. 1999/82 tentang Defamation of Religions (30 April 1999).

Resolusi Menteri Luar Negeri OKI, No. 44/17-P on the Draft Document on Human Rights in Islam. The Seventeenth Islamic Conference of Foreign Ministers held in Amman, Hashemite Kingdom of Jordan from 3-7 Sha'bān 1408H (21-25 March, 1988).

Resolution No. 41/18-p on the Draft Document on Human Rights in Islam. The Eighteenth Islamic Conference of Foreign Ministers, (Session of Islamic Fraternity and Solidarity), held in Riyadh, Kingdom of Saudi Arabia from 6-9 Sha'bān,1409H (13-16 March, 1989)

Resolution No. 49/19-P on the Cairo Declaration on Human Rights in Islam. The Nineteenth Islamic Conference of Foreign Ministers (Session of Peace, Interdependence and Development), held in Cairo, Arab Republic of Egypt, from 9-14 Muharram 1411H (31 July to 5 August 1990).

Resolution No. 3/29-Leg on Coordination Among Member States in the Field of Human Rights; lihat pula, Resolusi Komisi HAM PBB No. 1999/82 tentang Defamation of Religions (30 April 1999).

Secretary General's Report, New Vision for the Muslim World: Solidarity in Action Presented at the Third Extraordinary Session of the Islamic Summit Conference, Makkah al-Mukarramah, 7-8 December 2005.

Internet:

Mayer, Elizabeth Ann, "Debating the Universality of Human Rights; A Plea for a Critical Perspective", http://lgst.wharton.upenn.edu/mayera/ documents/ Hamudps3.pdf

Morrison, Heidi, "Beyond Universalism", dalam Muslim World Journal of Human Right, Volume 1, Issue 1 (October 2004), http://www.bepress.com/mwjhr/ vol1/iss1/art2

222 || Volume 23, Nomor 2, Oktober 2013

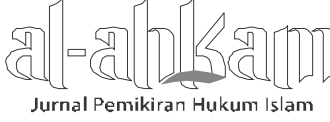


Dinamika Hukum dan Hak Asasi Manusia di Negara-negara Muslim

Pembukaan Piagam OKI. http:/ /www.oic-oci.org/is11/english/ Charter-en.pdf

Resolution No. 2/38-LEG, "The Establishment of the OIC Independent Permanent Human Rights Commission" diakses dari http://www.oic-oci.org/38cfm/ en/documents/res/LEG-RES-38-CFM-FINAL-2.pdf 
224 || Volume 23, Nomor 2, Oktober 2013 